\title{
Seasonal variation of hepatitis $B$ and $C$ virus infection among HIV- and non-HIV-infected patients in Benin City, Nigeria
}

\author{
Bankole H. Oladeinde ${ }^{1,2}$, Ifeoma M. Ekejindu², Richard Omoregie ${ }^{3,4}$ \\ ${ }^{1}$ Department of Medical Laboratory Science, Faculty of Basic Medical Science, College of Medical Sciences, Edo University, \\ Iyamho Edo State, Nigeria \\ ${ }^{2}$ Department of Medical Laboratory Science, Faculty of Health Science, College of Health Sciences, Nnamdi Azikiwe University, \\ Awka, Nigeria \\ ${ }^{3}$ School of Medical Laboratory Sciences, University of Benin Teaching Hospital, Benin City, Edo State, Nigeria \\ ${ }^{4}$ Medical Microbiology Unit, Medical Laboratory Services, University of Benin Teaching Hospital, Benin City, Nigeria
}

\begin{abstract}
Introduction: Seasonal variation in immunity has been found in healthy individuals and in association with some diseases. Data on seasonal prevalence of hepatitis B virus (HBV) and hepatitis C virus (HCV) infection is sparse. This study aimed at determining the seasonal seroprevalence of HBV and $\mathrm{HCV}$ infections among human immunodeficiency virus (HIV)-infected patients in Benin City.

Material and methods: A total of 1,177 HIV-positive and 503 non-HIV-positive patients were recruited for this study. Venous blood was collected from all participants and screened for the presence of HBsAg and anti-HCV antibody using immunochromatographic technique.

Results: The seroprevalence of HBV infection did not differ significantly with respect to season among HIV-infected patients (rainy season vs. dry season: $4.2 \%$ vs. $3.4 \%$; $\mathrm{OR}=1.271$; $95 \% \mathrm{CI}=0.695-2.322$; $p=0.451$ ), and non-HIV-infected patients (rainy season vs. dry season: $3.2 \%$ vs. $4.0 \%$; OR = 0.783 ; $95 \% \mathrm{CI}=0.305-2.020 ; p=0.639$ ). A statistically significant association was however observed between $\mathrm{HCV}$ seropositivity and rainy season among HIV-infected patients only (rainy season vs. dry season: $3.9 \%$ vs. $1.1 \%$; $\mathrm{OR}=3.789,95 \% \mathrm{CI}=1.537-9.342 ; p=0.003$ ).

Conclusions: HIV-infected patients in Nigeria are at risk of acquiring HCV infection during the rainy season. Control and prevention methods for HBV and HCV infections among HIV-infected patients are advocated.
\end{abstract}

HIV AIDS Rev 2018; 17, $1: 36-39$ DOI: https://doi.org/10.5114/hivar.2018.73337

Key words: HBV, HCV, HIV-infected patients, seasonality, Nigeria.

\section{Introduction}

Hepatitis B virus (HBV) and hepatitis C virus (HCV) infections are major public health concerns in both devel- oped and developing countries of the world. Sub-Saharan Africa is reported to have the highest burden of HBV and $\mathrm{HCV}$ infection in the world $[1,2]$. As a result of shared routes of transmission, co-infection of HCV and HBV is common
Address for correspondence: Dr. Bankole H. Oladeinde, Department of Medical Laboratory Sciences, Faculty of Basic Medical Sciences, College of Medical Sciences, Edo University, Iyamho Edo State, Nigeria, phone: +2348053096120 , e-mail: bamenzy@yahoo.com
Article history:

Received: 29.06.2017

Received in revised form: 12.10.2017

Accepted: 10.01.2018

Available online: 19.01.2018
International Journal of HIV-Related Problems

HIV \& AIDS Re vi e w 
among human immunodeficiency virus (HIV)-infected patients $[3,4]$. Nigeria is Africa's most populous nation, and is home to more people living with HIV than any other country in the world, except South Africa and India [5]. Reports indicate that HIV-positive patients infected with HCV and/ or HBV have increased risk of liver disease worldwide [6]. An increase in the rate of progression of HIV infection to AIDS has been reported among HIV-positive patients with HBV and/or HCV infection [7-10].

Viral hepatitis is present throughout the year, with its prevalence rates reported to be higher in some particular months of the year in most of the countries around the world [11]. While studies have evaluated the effect of seasonal variation on prevalence of $\mathrm{HBV}$ and $\mathrm{HCV}$ infections, none have strictly focused on HIV-infected populations. Data on seasonal variation of HBV and HCV infection among HIV-negative patients is lacking in Nigeria. Against this background, this study aimed at determining the effect of season on seroprevalence of $\mathrm{HBV}$ and $\mathrm{HCV}$ infection among HIV- and nonHIV subjects in Benin City, Nigeria.

\section{Material and methods}

\section{Study population}

This study spanning from March 2014 to November 2015, was conducted among patients attending the University of Benin Teaching Hospital (UBTH) Benin City, Nigeria. The University of Benin Teaching Hospital is a tertiary teaching hospital with a referral status, located in the SouthSouth geopolitical zone of Nigeria.

A total of 1,177 HIV-positive and 503 non-HIV-infected patients were recruited in two batches for this study. First batch of patients, consisting of 613 HIV-positive and 253 non-HIV-infected patients, was recruited in months that coincided with rainy season of the year. The second batch of patients, consisting of $564 \mathrm{HIV}$-positive and 250 non-HIV-positive patients, was enlisted for study during the dry season of the year. In Midwestern Nigeria, the annual dry season spans from October to April, while the rainy season last from May to September, with a characteristic one week August break, in which rainfall abates [12]. Informed consent was obtained from all subjects prior to collection of specimen. In the case of minors, consent was obtained from their parents or guardians. The research was conducted in line with the Helsinki declaration.

\section{Specimen collection and processing}

Five milliliter of venous blood was collected from consenting patients and placed in a plain container, allowing to clot. The blood serum obtained was used for the serological diagnosis of HIV, using a previously described method [13]. $\mathrm{HCV}$ antibodies were detected from HIV-infected and non-HIV-infected patients, using immunochromatographic method - Clinotech Anti-HCV (Clinotech Diagnostics,
Richmond, Canada). Serodiagnosis of HBV was performed using Determine ${ }^{\mathrm{TM}} \mathrm{HBsAg}$ immunochromatographic test (Abbott Laboratories, USA). HCV and HBV serodiagnosis were done following manufacturers instruction.

\section{Statistical analysis}

The data obtained were analyzed using $\chi$-Square $\left(c^{2}\right)$ test and odd ratio analysis, using the statistical software INSTAT ${ }^{\circledR}$ (Graphpad software Inc., La Jolla, CA, USA). Statistical significance was set at $p<0.05$.

\section{Result}

Among HIV-infected patients, a higher seroprevalence of $\mathrm{HBV}$ was recorded during the rainy season of the year (rainy season vs. dry season: $4.2 \%$ vs. $3.4 \%$ ). The reverse was the case among non-HIV-infected patient, where a higher prevalence was recorded in the dry than rainy season of the year (rainy season vs. dry season: $3.2 \%$ vs. $4.0 \%$ ). Generally, the seroprevalence of HBV infection did not differ significantly with respect to season among HIV-infected $(p=0.451)$ and non-HIV subjects $(p=0.639)$ (Table 1$)$.

A statistically significant association was found between HCV seropositivity and rainy season among HIV-infected patients (rainy season vs. dry season: $3.9 \%$ vs. $1.1 \%$; $\mathrm{OR}=3.789$; $95 \% \mathrm{CI}=1.537-9.342 ; p=0.003)$. As observed in the HIVinfected group of patients, a higher seroprevalence of HCV was recorded among non-HIV-infected patients in the rainy than dry season of the year (rainy season vs. dry season: $1.2 \%$ vs. $0.4 \%$ ), with the difference however failing to reach statistically significant proportion $(p=0.624)$ (Table 2$)$.

\section{Discussion}

Seasonal variation in immunity has been found in healthy individuals and in association with some diseases [14]. There is paucity of data on effect of seasonal variation on prevalence of HBV and HCV infection. To our knowledge, no study has reported the effect of season on prevalence of HBV and HCV infection among HIV-infected patients. Against this background, this study aimed at determining the seasonal variation of $\mathrm{HBV}$ and $\mathrm{HCV}$ infections among HIV- and non-HIV-infected patients in Benin City Nigeria.

In this study, HIV-infected patients were observed to have a higher seroprevalence of HBV infection during the rainy than dry season of the year. A contrasting report has been documented elsewhere. In a Gambian study, the highest prevalence of $\mathrm{HBV}$ infection was recorded within the months of April to June [15], coinciding with dry season in Gambia [16]. It is important to note that Villar et al. [15] have reported the prevalence of active (HBeAg-positive) and true HBV (HBV-DNA-positive) infection in contrast to ours, which determined the seroprevalence of HBV infection. This may explain the observed variation in report. The variation could also be due to differences in nature of study population as that 
Table 1. Seasonal variation in seroprevalence of hepatitis B virus infection among patients

\begin{tabular}{|c|c|c|c|c|c|}
\hline Variable & $n$ & No HBV-Pos (\%) & OR & $95 \% \mathrm{Cl}$ & $p$ value \\
\hline \multicolumn{6}{|l|}{ HIV-positve } \\
\hline Rainy season & 613 & $26(4.2)$ & 1.271 & $0.695-2.322$ & \multirow{2}{*}{0.451} \\
\hline Dry season & 564 & $19(3.4)$ & 0.787 & $0.431-1.438$ & \\
\hline \multicolumn{6}{|l|}{ HIV-negative } \\
\hline Rainy season & 253 & $8(3.2)$ & 0.783 & $0.305-2.020$ & \multirow{2}{*}{0.639} \\
\hline Dry season & 250 & $10(4.0)$ & 1.276 & $0.495-3.289$ & \\
\hline
\end{tabular}

Pos-positive

Table 2. Seasonal variation in seroprevalence of hepatitis $C$ virus infection among patients

\begin{tabular}{|c|c|c|c|c|c|}
\hline Variable & $n$ & No HBV-Pos (\%) & OR & $95 \% \mathrm{Cl}$ & $p$ value \\
\hline \multicolumn{6}{|l|}{ HIV-positve } \\
\hline Rainy season & 613 & $24(3.9)$ & 3.789 & $1.537-9.342$ & \multirow{2}{*}{0.003} \\
\hline Dry season & 564 & $6(1.1)$ & 0.264 & $0.107-0.650$ & \\
\hline \multicolumn{6}{|l|}{ HIV-negative } \\
\hline Rainy season & 253 & $3(1.2)$ & 2.988 & $0.308-28.931$ & \multirow{2}{*}{0.624} \\
\hline Dry season & 250 & $1(0.4)$ & 0.335 & $0.034-3.241$ & \\
\hline
\end{tabular}

of Villar et al. [15], was one with subjects of unknown HIV status, in contrast to ours, where the subjects were HIV positive. However, among the non-HIV-infected subjects, a higher seroprevalence of $\mathrm{HBV}$ infection was observed during the dry than rainy season of the year. Reason for this finding is not clear. Generally, the seroprevalence of HBV was not found to be significantly different with respect to season among HIVand non-HIV-infected patients in this study.

A statistically significant association was found between HCV seropositivity and rainy season in this study. HIV-infected patients were found to be about four times significantly more likely to be HCV-seropositive during the rainy than dry season of the year. HIV-negative patients were observed to have a higher seroprevalence of HCV during the rainy season than dry season, although the difference was statistically insignificant The most efficient route of transmission of HCV is through a large or repeated direct percutaneous exposures to blood (e.g., transfusion or transplantation from infectious donors, injecting drug use [17]). Reports have shown that the demand for blood in Nigeria is highest during the rainy season of the year [18]. Frequent receipt of blood by HIV- and non-HIV-infected patients during the rainy season may expose them to greater risk of acquiring HCV infection. This may account for observed higher seroprevalence of HCV infection during the rainy season in this study. Illicit drug use has been reported as a risk factor for HCV infection in a previous African study [19]. Reports show that among American teens, illicit drug use is higher during the winter (cold season) than summer (dry and sunny season) of the year [11]. In a bid to remain warm in the rainy season, illicit drugs use may escalate among HIV and non-HIV subjects in this study, exposing them to acquire $\mathrm{HCV}$ infection. Conclusions made in this study were based on serological detection of HBsAg and HCV antibodies. This is an observed limitation to study. Studies to determine seasonal variation of true HBV and HCV infections using molecular diagnostic technologies is warranted.

\section{Conclusions}

In summary, a significantly higher seroprevalence of HCV infection was observed in the rainy than dry season of the year among HIV-infected patients. Improved HBV and HCV screening among HIV- and non-HIV-infected patients in Nigeria is encouraged.

\section{Acknowledgement}

Authors would like to express their gratitude to all who consented and participated in this study.

\section{Conflict of interest}

The authors declare no potential conflicts of interest with respect to the research, authorship, and/or publication of this article.

\section{References}

1. Karoney MJ, Siika AM. Hepatitis C Virus (HCV) infection in Africa: review. Pan Afr Med J 2013; 14: 44.

2. Ikobah J, Okpara H, Elemi I, et al. The prevalence of hepatitis B virus infection in Nigerian children prior to vaccine introduction 
into the National Programme on Immunization schedule. Pan Afr Med J 2012; 23: 128.

3. Thio CL. Hepatitis B and Human Immunodeficiency Virus coinfection. Hepatology 2009; 49: 138-145.

4. Sulkowski MS. Current Management of Hepatitis C Virus infection in patients with HIV co-infection. J Infect Dis 2013; 207: 26-32.

5. Monjok, E, Smesny A, Essien EJ. HIV/AIDS-Related Stigma and Discrimination in Nigeria: Review of Research Studies and future directions for Prevention Strategies. Af J Reprod Health 2009; 13: 21-35.

6. Mboto CI, Fielder M, Davies-Russell A, et al. Co-infection with human immunodeficiency virus (HIV) is associated with significant morbidity and mortality. Hepatitis $\mathrm{C}$ virus prevalence and serotypes associated with HIV in The Gambia. Br J Biomed Sci 2010; 67: 140-144.

7. Greub G, Ledergerber B, Battegay M, et al. Clinical progression, survival, and immune recovery during antiretroviral therapy in patients with HIV-1 and hepatitis C virus coinfection: the Swiss HIV Cohort Study. Lancet 2000; 356: 1800-1805.

8. Daar ES, Lynn H, Donfield S, et al. Hepatitis C virus load is associated with human immunodeficiency virus type 1 disease progression in hemophiliacs. J Infect Dis 2001; 183: 589-595.

9. Chun HM, Carpenter RJ, Macalino GE, et al. The Role of Sexually Transmitted Infections in HIV-1 Progression: A Comprehensive Review of the Literature. J Sex Trans Dis 2013; 45: 231-239.

10. Thio CL, Smeaton L, Saulynas M, et al. Characterization of HIV$\mathrm{HBV}$ co-infection in a multinational HIV-infected cohort. AIDS 2013; 27: 191-201.

11. Fares A. Seasonality of Hepatitis: A Review Update. J Fam Med Prim Care 2015; 4: 96-100.

12. Olele NF, Ekelemu JK. Physicochemical and periphyton/phytoplankton study of Onah Lake, Asaba, Nigeria. Afr J Gen Agric 2008; 4: 183-193.

13. Omoregie R, Efam MO, Ihongbe JC, et al. Sero-prevalence of HIV infection among psychiatric patients in Benin City, Nigeria. Neurosciences 2009; 14: 100-101.

14. Zhang SJ, Chen ZX, Jiang KP, et al. Effect of seasonal variation on the clinical course of chronic hepatitis B. J Gastroenterol 2006; 41: 1107.

15. Villar S, Roux-Goglin EL, Gouas DA, et al. Seasonal variation in Tp53 R249S-mutated serum DNA with aflatoxin exposure and hepatitis B virus infection. Environ Health Perspect 2011; 119: 1635-1640.

16. Jawara M, Pinder M, Drakeley CJ, et al. Dry season ecology of Anopheles gambiae complex mosquitoes in The Gambia. Malaria J 2008; 7: 156.

17. Alter MJ. Epidemiology of hepatitis C virus infection. World J Gastroenterol 2007; 13: 2436-2441.

18. Erhabor O, Adias TC. The challenges of meeting the blood transfusion requirements in Sub-Saharan Africa: the need for the development of alternatives to allogenic blood. J Blood Med 2011; 2: 17-21.

19. Jimenez AP, Mohamed MK, Eldin NS, et al. Injection Drug Use Is a Risk Factor for HCV Infection in Urban Egypt. PLoS One 2009; 4: e7193. 